\title{
Longitudinal protein changes in blood plasma associated with the rate of cognitive decline in Alzheimer's disease
}

\author{
Martina Sattlecker ${ }^{1,2}$, Mizanur Khondoker ${ }^{1,2}$, Petroula Proitsi ${ }^{1,2}$, Stephen Williams ${ }^{3}$, Hilkka \\ Soininen ${ }^{4}$, Iwona Kłoszewska ${ }^{5}$, Patrizia Mecocci ${ }^{6}$, Magda Tsolaki ${ }^{7}$, Bruno Vellas ${ }^{8}$, Simon \\ Lovestone $^{1,2}$ on behalf of the AddNeuroMed Consortium and Richard JB Dobson ${ }^{1,2}$ \\ ${ }^{1}$ King's College London, Institute of Psychiatry, Psychology \& Neuroscience, London, UK \\ ${ }^{2}$ NIHR Biomedical Research Centre for Mental Health and Biomedical Research Unit for \\ Dementia at South London and Maudsley NHS Foundation Trust \\ ${ }^{3}$ SomaLogic, Boulder, Colorado, United States of America \\ ${ }^{4}$ Department of Neurology, University of Eastern Finland and Kuopio University Hospital, \\ Kuopio, Finland \\ ${ }^{5}$ Medical University of Lodz, Lodz, Poland \\ ${ }^{6}$ Institute of Gerontology and Geriatrics, University of Perugia, Perugia, Italy \\ 7 3rd Department of Neurology, Aristotle University, Thessaloniki, Greece \\ 8 INSERM U 558, University of Toulouse, Toulouse, France
}

Corresponding authors: Martina Sattlecker and Richard Dobson, NIHR Biomedical Research Centre for Mental Health South London and Maudsley NHS Foundation Trust \& King's College London, Institute of Psychiatry, De Crespigny Park, London, UK. E-mail: martina.sattlecker@kcl.ac.uk, richard.j.dobson@kcl.ac.uk, Telephone: +44(0) 2078480236 


\section{Abstract}

Biomarkers of Alzheimer's disease (AD) progression are needed to support the development of urgently needed disease modifying drugs. We employed a SOMAscan assay for quantifying 1,001 proteins in blood samples from 90 AD subjects, 37 stable mild cognitive impaired $(\mathrm{MCl})$ subjects, $39 \mathrm{MCl}$ subjects converting to $A D$ within a year and 69 controls at baseline and one year follow up. We used linear mixed effects models to identify proteins changing significantly over one year with the rate of cognitive decline, which was quantified as the reduction of Mini Mental State Examination (MMSE) scores. Additionally we investigated proteins changing differently across disease groups and during the conversion from $\mathrm{MCl}$ to $\mathrm{AD}$. We found that levels of proteins belonging to the complement cascade increase significantly in fast declining $A D$ patients. Longitudinal changes in the complement cascade might be a surrogate biomarker for disease progression. Additionally we found that members of the cytokine-cytokine receptor interaction pathway change during $A D$ when compared to healthy aging subjects.

Keywords: Alzheimer's disease, cognitive decline, complement cascade, cytokine-cytokine receptor interaction, plasma proteins 


\section{Introduction}

Alzheimer's disease (AD), the most common form of dementia, is a devastating illness characterized by progressive short-term memory loss, followed by the inability of patients to care for themselves and leading to eventual death 10-15 years after diagnosis. To date there is no cure and available medication can only temporarily alleviate some symptoms or slow down progression in a subset of patients. Thus new drugs are urgently needed.

To support the development of disease modifying drugs, biomarkers for early diagnosis and disease progression are required [1] and blood based biomarkers have been the focus of much recent work as blood can be accessed for repeated measures relatively easily. Of particular note is the growing body of work around changes in plasma proteins in relation to $\mathrm{AD}$ and/or MCl-related protein biomarkers using Mass Spectrometry and antibody capture technologies [2-10].

The majority of studies have investigated the potential of blood proteins by only considering cross sectional measures. In this study we investigated longitudinal protein changes associated with the rate of cognitive decline in $A D$ patients. Additionally, we compared longitudinal protein changes between normal aging and changes during $A D$, and changes occurring during the transition from $\mathrm{MCl}$ to $\mathrm{AD}$.

\section{Methods}

\subsection{Subjects}

We obtained protein measures for 235 subjects (69 controls, 37 'stable' $\mathrm{MCl}$ (MCls), $39 \mathrm{MCl}$ converting to $A D$ within a year (MClc) and $90 \mathrm{AD}$ ) from the EU funded AddNeuroMed (ANM) biomarker study [11, 12]. Informed consent was obtained for all subjects according to the Declaration of Helsinki (1991), and protocols and procedures were approved by the relevant local ethical committees at each site. All subjects were assessed with a standardised assessment protocol including informant interview for diagnosis, cognitive assessment such 
as the Mini Mental State Examination (MMSE) together with standardised assessment of function, behaviour and dementia severity as previously reported $[3,9,10]$.

\subsection{Blood samples}

At the time of assessment, all blood samples were drawn by venipuncture and collected into EDTA glass tubes. Subjects were required to fast for at least 2 hours prior to collection. All samples were centrifuged at $2000 \mathrm{~g}$ for $10 \mathrm{~min}$ at $4 \sqsubset \mathrm{C}$ within approximately $2 \mathrm{~h}$ of collection. Plasma supernatant was collected, divided into aliquots, and frozen at $-80 \square \mathrm{C}$ until further use.

\subsection{Protein measures}

Proteins were measured using a Slow Off-rate Modified Aptamer (SOMAmer)-based capture array called 'SOMAscan' (SomaLogic, Inc, Boulder, Colorado). This approach uses chemically modified nucleotides to transform a protein signal to a nucleotide signal that can be quantified using relative florescence on microarrays. Therefore all gathered SOMAscan measures are relative fluorescence units (RFU). This assay has been shown to have a median intra- and inter-run coefficient of variation of $\sim 5 \%$. The median lower and upper limits of quantification were $\sim 1 \mathrm{pM}$ and $\sim 1.5 \mathrm{nM}$ in buffer, and $\sim 2.95 \mathrm{pM}$ and $\sim 1.5 \mathrm{nM}$ for a subset of the somamers in plasma, full details are given in Gold et al. [13].

Quality control was performed at the sample and SOMAmer level, and involved the use of control SOMAmers on the microarray and calibration samples. At the sample level, hybridization controls on the microarray were used to monitor sample-by-sample variability in hybridization, while the median signal over all SOMAmers was used to monitor overall technical variability. The resulting hybridization scale factor and median scale factor were used to normalize data across samples. The acceptance criteria for these values was $0.4-2.5$, based on historical trends in these values. SOMAmer-by-SOMAmer calibration occurred through the repeated measurement of calibration samples, these samples were of the same matrix as the study samples, and were used to monitor repeatability and batch to batch 
variability. Historical values for these calibrator samples for each SOMAmer were used to generate a calibration scale factor. The acceptance criteria for calibrator scale factors was $95 \%$ of SOMAmers having a calibration scale factor within \pm 0.4 of the median.

The assay required $8 \mu \mathrm{L}$ of plasma from each sample. A single assay was used per plasma sample, and thus no technical replicates were performed. All measurements were log2 transformed.

The assay measures the level of 1,001 human proteins representing different molecular pathways and gene families. The majority of proteins are involved in the following processes: signal transduction pathways, stress response, immune process and phosphorylation, but in addition proteolysis, cell adhesion, cell differentiation and intracellular transport proteins are represented.

\subsection{Statistical analysis}

All statistical analyses were performed using $R$ and the library 'nlme' version 3.1 [14]. Firstly, we investigated the association between change in protein level (follow-up minus baseline) and the rate of cognitive decline in $A D$ subjects at the single analyte level. Cognitive decline was calculated by fitting a multi-level linear mixed model to the longitudinal Mini Mental State Examination (MMSE) assessments, which were gathered over five visits during a one year follow-up period. Subjects and centre were included as random effects in the model. Further covariates including age of onset, disease duration at baseline, gender, presence of apolipoprotein $(A P O E) \varepsilon 4$ allele, living in a nursing home and years of education were added as fixed effects. The associations between protein changes and the rate of MMSE decline was assessed by including a protein change by time interaction in within the multi-level model.

Additionally we aimed to identify proteins changing over time in the diagnostic groups relative to controls, and therefore possibly associated with disease progression. For each individual 
protein we estimated the rate of change by using a multi-level linear model with random intercepts for subject and centre level clustering. The slope was fixed as there were only protein measures at two time points, namely baseline and follow-up. Age, gender and apolipoprotein $(A P O E) \varepsilon 4$ allele presence were included as fixed covariates. In order to estimate and test the association between protein changes and disease status, we included a time by diagnosis interaction term in the model. Control subjects were set as the reference level to which all the disease groups were compared. Dummy coding was applied for the three disease groups (MCls, MClc and $A D$ ). We used the same approach to identify proteins, which are changing during the transition from $\mathrm{MCl}$ to $A D$ relative to unchanging $\mathrm{MCl}$ subjects. Stable $\mathrm{MCl}$ subjects were set as the reference to which $\mathrm{MCl}$ subjects converting to $\mathrm{AD}$ were compared $(\mathrm{MCls}=0, \mathrm{MClc}=1)$

All p-values were FDR (false discovery rate) adjusted and an association was considered significant if it passed a threshold of $\mathrm{q}$-value $<0.05$. However, we also considered associations passing a threshold of $p$-value $<0.01$ as nominally significant.

\subsection{Enrichment analysis}

Enrichment analysis for pathways (KEGG) and Gene Ontologies (molecular function, cellular component and biological process) was performed on significantly associated proteins (qvalue $<0.05)$ using the DAVID knowledgebase $[15,16]$. In the case that only small number of proteins passed the threshold a more exploratory threshold of $p$-value $<0.01$ was used. The background for enrichment was set to the full list of proteins measured on the SomaLogic panel.

Again, all p-values were FDR (false discovery rate) adjusted and enrichment was considered significant if it passed a threshold of $q$-value $<0.05$ and nominally significant at a $p$-value $<$ 0.01 . 


\section{Results}

\subsection{Demographics}

Demographic characteristics stratified by diagnostic group are provided in Table 1 . Differences in demographic characteristics according to clinical diagnosis were assessed using a one-way ANOVA. Significant differences were found for age, number of $A P O E \varepsilon 4$ alleles and MMSE score at baseline; no significant differences in gender were observed.

\section{$<$ Table 1>}

\subsection{Protein changes associated with the rate of decline in AD patients}

Twelve proteins were found to be significantly associated with rate of progression on an exploratory level ( $p$-value < 0.01) (See Table 2): C2 (Complement C2), SAA (Serum amyloid A-1 protein), C9 (Complement C9), MBL (Mannose-binding protein C), SAP (Serum amyloid P-component), a2-Antiplasmin, CHK1 (Serine/threonine-protein kinase Chk1), IL-17 (Interleukin-17A), elF-5A-1 (Eukaryotic translation initiation factor 5A-1), Hemopexin, CDC37 (C-C motif chemokine 19) and Complement factor H-related protein 5. Both C2 and SAA passed multiple testing corrections at a q-value threshold of $<0.05$. Ten out of 12 proteins showed a negative association with rate of cognitive decline and therefore increasing levels of these proteins can be associated with high loss in MMSE scores per year or in other words with fast decline. Only elF-5A-1 and CDC37 showed a positive association with the rate of cognitive decline and therefore increasing levels of these proteins are associated with lower loss in MMSE scores per year or in other words with slow decline. Scatter plots of the four proteins showing the most significant change with rate of cognitive decline are shown in Figure 1.

$<$ Table 2 >

$<$ Figure $1>$ 
The 12 proteins passing the threshold of $p$-value $<0.01$ (Table 2) were significantly enriched in members of the complement and coagulation cascades (q-value $=0.005$, KEGG hsa04610). These proteins are: MBL, C9, C6, and a2-Antiplasmin. We also found significant enrichment ( $q$-value $<0.05$ ) of proteins involved in 24 biological processes, including acute inflammatory response ( $q$-value $=0.0003$ ), inflammatory response ( $q$-value $=0.002$ ), defense response ( $q$-value $=0.011$ ) and complement activation ( $q$-value $=0.015)$.

\subsection{Protein changes across disease groups}

$X$ Proteins were found to be changing $(q-v a l u e<0.05)$ in $\mathrm{MCls}$ and in $A D$ over time relative to controls (See Table 3). HCC-1 (C-C motif chemokine 14) was the only protein showing significant changes when comparing in the MCls group. Changes in HCC-1 levels were also significant at a suggestive $p$-value of $<0.05$ between the AD and control group. Ten proteins showed a significant change in levels between the $A D$ and control group. Notably protein levels gradually decrease over time with more established disease and thus AD patients showed a generally larger decrease in protein levels than $\mathrm{MCls}$ over a year. Raw differences in plasma levels are shown in Figure 2 for the four strongest associations.

The 11 proteins changing in in $A D$ did not show significant enrichment, not even at the exploratory level ( $p$-value<0.01), for KEGG pathways, GO molecular function, cellular components or biological processes.

$<$ Table $3>$

$<$ Figure $2>$

\subsection{Protein level changes associated with conversion from $\mathrm{MCl}$ to $\mathrm{AD}$}

No protein was found to show significant enough changes during conversion from $\mathrm{MCl}$ to $\mathrm{AD}$ to pass multiple testing correction (q-value $<0.05$ ) when compared to stable $\mathrm{MCl}$. However 
nine proteins, SDF-1a (Stromal cell-derived factor 1 alpha, $p$-value=3.3E-5), SLPI (Antileukoproteinase, p-value=8.5E-4), HCC-1 (C-C motif chemokine 14, p-value=0.002), BCMA (Tumor necrosis factor receptor superfamily member $17, p$-value $=0.005$ ), LTA-4 hydrolase (Leukotriene A-4 hydrolase, $p$-value $=0.006$ ), Endostatin ( $p$-value $=0.006$ ), Trypsin ( $p$-value=0.006), IL-6 sRa (Interleukin-6 receptor subunit alpha, $p$-value $=0.007$ ) and Albumin $(p$-value $=0.010)$ passed a suggestive threshold of $p$-value $<0.01$ (Table 4$)$.

The nine proteins were not significantly enriched for any pathway or Gene Ontologies at an uncorrected p-value.

\section{$<$ Table 4 >}

\subsection{Assay performance}

In order to assess the quantitative performance of the assay for $\mathrm{C} 2, \mathrm{C}$, MBL and SAA, limit of quantification (LOQ) six-point standard curves spanning six logs in concentration, from 10 $\mathrm{nM}$ to $10 \mathrm{fM}$, in buffer were generated. The upper limit of quantification (ULOQ), the lower limit of quantification (LLOQ) and the dynamic range of quantification (ROQ) were measured. Standard curves and precision profiles for all four analytes are shown in Supplementary Material 1.

\section{Discussion}

In this study, we investigated the relationship between changes in 1,001 proteins and rate of Alzheimer's disease progression, as measured by change in MMSE scores. As we had longitudinal measures only for a subset of samples (69 controls, 37 'stable' $\mathrm{MCl}$ (MCls), 39 $\mathrm{MCl}$ converting to $\mathrm{AD}$ within a year $(\mathrm{MCl})$ ) and $90 \mathrm{AD}$ ) cross-sectional results for the complete data set comprising protein measures for 691 subjects $(211$ controls, $106 \mathrm{MCl}$ patients, $43 \mathrm{MCl}$ patients converting to $\mathrm{AD}$ within a year, and $331 \mathrm{AD}$ patients) wereWe previously reported a cross sectional analysis in a superset of these samples $[4,7]$. 
We found that proteins exhibiting rate of cognitive decline associated changes were enriched with proteins from the complement cascade,namely MBL (Mannose-binding protein C), C2 (Complement C2), and C9 (Complement C9). All three were shown to be increasing more rapidly in $A D$ patients with faster cognitive decline. They are found at the earliest stages of amyloid deposition and their activation coincides with the clinical expression of $\operatorname{AD}[17,18]$. The complement cascade is activated through three pathways: the classical, alternative and lectin pathway [19]. Target recognition of the three pathways varies, but they all share the common step of activating the central component C3 [20]. Mannose-binding protein C (MBL) activates the lectin pathway following the recognition and binding of pathogen-associated molecular patterns [20]. MBL activates the MBL-associated serine protease that leads to activation of Complement $\mathrm{C} 4$ and Complement $\mathrm{C} 2$ [21]. We found strong associations between $\mathrm{C} 2$, and $\mathrm{MBL}$ changes and the rate of cognitive decline and a statistically significant change in C9, also a component of the lectin complement pathway. Therefore our results suggest that changes in products of the lectin complement pathway are associated with fast cognitive decline. To our knowledge this is the first study to report an association between changes in the lectin complement pathway and the rate of cognitive decline in AD patients. C2 and C9 are also members of the classic pathway, which has an established association with $A D$ as it was found to be directly activated in vitro by fibrillar $A \beta 40$ and $A \beta 42$ by binding to $\mathrm{C} 3$ and the globular heads of $\mathrm{C} 1 \mathrm{q}[22]$.

We also found that Serum amyloid P-component (SAP) levels increase more in individuals with a fast cognitive decline. SAP is reported to co-localise with $A \beta$ plaques in human $A D$ brain [23, 24], exhibit up-regulated synthesis in $A D$ affected brain regions [25], induce neuronal apoptosis in vitro [26, 27] and protect senile plaques from proteolysis [28]. Increasing levels of SAP could potentially create an increasingly neurotoxic environment and therefore result in a faster cognitive decline in AD patients. Interestingly SAP can also activate the classical complement pathway via C1q [29]. Thus, greater increase of SAP, together with increased levels of Complement C2 and Complement C9 levels could also be an indication of increased levels of components of the classic complement pathway components in $\mathrm{AD}$ patients with fast cognitive decline. 
To our knowledge this is the first study to report a correlation in the level of members of the complement cascade associated with and rate of decline. Although our study is limited by the fact that we only observed protein changes over a year, a short timeframe for a slow developing disease such as $A D$, and a longer follow up of cognitive as well as protein changes in plasma would be needed to further support our findings.

SAP has been previously reported as a diagnostic AD candidate biomarker in the literature [4] albeit it with conflicting direction of association [3, 10, 30,31]. Although we found changes in SAP to be associated with rate of decline we did not observe significant changes of SAP when comparing diagnostic groups against controls.

The comparison of protein changes across clinical diagnostic groups showed that the most significant changes are in $A D$ subjects when compared to controls. However, the sample number for stable $\mathrm{MCl}$ and converting $\mathrm{MCl}$ patients was smaller than the $\mathrm{AD}$ group, resulting in lower statistical power for these groups. We found that proteins passing multiple testing correction for the $A D$ group were generally reducing over time. Among the proteins four were identified as being involved in cytokine-cytokine receptor interactions: Ck- $\beta-8-1$, MIP-1 $\alpha$, VEGFA, BMP RII and HCC-1. A number of studies have previously identified cytokine proteins as being predictive of clinical $A D$ diagnosis and progression from $M C l$ to $A D$ with high accuracy [6, 32-34]. Leung et al. [35] investigated plasma levels of cytokines changing with the rate of cognitive decline. This study investigated 27 cytokines of which 14 were also measured on our panel. They found a significant increase $(p$-value $<0.05)$ in the levels of IL-4, IL-10, and granulocyte-colony stimulating factor in $A D$ patients with a fast cognitive decline compared to slow cognitive decline. IL-4 was not measured on our panel. IL-10 and granulocyte-colony stimulating factor were not found to be significant in our study.

No significant enrichment for pathways or gene ontology terms was found in protein changes during the conversion from $\mathrm{MCl}$ to $\mathrm{AD}$. Generally associations were weak with no proteins passing multiple testing correction, possibly in part due to the low sample number. Protein 
levels of SDF-1a (Stromal cell-derived factor 1 alpha) showed the most significant increase and it has been suggested that SDF-1a could act in the central nervous system as a classical neuromodulator under normal conditions [36, 37]. Enhanced production of SDF-1a is suspected to affect neuronal and neuroendocrine activities, consequently alter brain function and lead to pathological behaviors and/or neurotoxicity [38]. Our findings might support the idea that increasing levels of SDF-1 $\alpha$ are occurring during the transition from $\mathrm{MCI}$ to $\mathrm{AD}$. We found a suggestive association between Albumin and the conversion from $\mathrm{MCl}$ to $\mathrm{AD}$ Albumin $(p-v a l u e=0.010)$. Albumin has been previously associated with $A D[3,9,32,39]$. In a recent review, we found that Albumin was associated with an AD-related phenotype in four independent research cohorts [4]. We also found that Albumin was also associated with Parkinson's Disease, Schizophrenia and Depression [40]. The majority of associations between $A D$ and albumin is positive, while association with Parkinson's Disease [41-44] Schizophrenia [45-47] and Depression [48-53] were mainly negative [40]. Albumin is an acute-phase protein, which can increase or decrease in plasma concentrations as part of an inflammatory response. In addition Albumin, is also generally used as a nutritional marker [49] and thus might only reflect nutritional status.

Another protein found to be associated on a suggestive level with conversion from $\mathrm{MCl}$ to $\mathrm{AD}$ was Trypsin ( $p$-value $=0.006)$. Literature suggests that $A \beta$ may play a direct role in protease activities, for instance it was shown that fibrillar $A \beta$, a key component of $A D$ plaques, is resistant to proteolytic digestion [54]. Further it was reported that fibrillar $A \beta$ inhibits the proteolytic activity of Trypsin and that soluble A $\beta$ is a substrate for Trypsin [55]. We found higher Trypsin levels in subjects converting to $A D$ than stable $\mathrm{MCl}$ subjects and therefore our findings may support hypothesis that that Trypsin is involved in the A $\beta$ catabolism.

We have presented the largest longitudinal study to date of changes in plasma protein levels associated with rate of disease progression and clinical diagnosis. Our results suggest that levels of complement pathway products are elevated in faster declining AD patients Thus longitudinal changes in the complement cascade might be a surrogate biomarker for disease progression and also be a promising target for $A D$ drug discovery. However, we only 
investigated protein plasma levels changing over one year, therefore studies with a longer follow up time are needed for further validation.

\section{Acknowledgement}

This work was supported by InnoMed, (Innovative Medicines in Europe) an Integrated Project funded by the European Union of the Sixth Framework program priority [FP6-2004LIFESCIHEALTH-5]; the Alzheimer's Research Trust; The John and Lucille van Geest Foundation and the NIHR Biomedical Research Centre for Mental Health and Biomedical Research Unit for Dementia at the South London and Maudsley NHS Foundation Trust and Kings College London, and a joint infrastructure grant from Guy's and St Thomas' Charity and the Maudsley Charity; Kuopio University Hospital (HS) and funding from UEFBRAIN (HS). SOMAscan ${ }^{\mathrm{TM}}$ and SOMAmer ${ }^{\mathrm{TM}}$ are trademarks of SomaLogic, Inc.

\section{Disclosure statement}

Intellectual property has been registered on the use of plasma proteins for use as biomarkers for AD by King's College London and Proteome Sciences, with Simon Lovestone named as an inventor. Stephen Williams is employee of SomaLogic Inc. and the proteomic assay reported in this manuscript was performed using reagents supplied by SomaLogic, Inc.

[1] Bazenet C, Lovestone S (2012) Plasma biomarkers for Alzheimer's disease: much needed but tough to find. Biomark Med 6, 441-454.

[2] Buerger K, Ernst A, Ewers M, Uspenskaya O, Omerovic M, Morgenthaler NG, Knauer K, Bergmann A, Hampel H (2009) Blood-Based Microcirculation Markers in Alzheimer's Disease-Diagnostic Value of Midregional Pro-atrial Natriuretic Peptide/Cterminal Endothelin-1 Precursor Fragment Ratio. Biological Psychiatry 65, 979-984.

[3] Hye A, Lynham S, Thambisetty M, Causevic M, Campbell J, Byers HL, Hooper C, Rijsdijk F, Tabrizi SJ, Banner S, Shaw CE, Foy C, Poppe M, Archer N, Hamilton G, Powell J, Brown RG, Sham P, Ward M, Lovestone S (2006) Proteome-based plasma biomarkers for Alzheimer's disease. Brain 129, 3042-3050.

[4] Kiddle SJ, Sattlecker M, Proitsi P, Simmons A, Westman E, Bazenet C, Nelson SK, Williams S, Hodges A, Johnston C, Soininen H, Kloszewska I, Mecocci P, Tsolaki M, Vellas B, Newhouse S, Lovestone S, Dobson RJB (2014) Candidate Blood Proteome Markers of Alzheimer's Disease Onset and Progression: A Systematic Review and Replication Study. Journal of Alzheimers Disease 38, 515-531.

[5] O'bryant SE, Xiao GH, Barber R, Reisch J, Hall J, Cullum CM, Doody R, Fairchild T, Adams P, Wilhelmsen K, Diaz-Arrastia R, Consorti TARC (2011) A Blood-Based 
Algorithm for the Detection of Alzheimer's Disease. Dementia and Geriatric Cognitive Disorders 32, 55-62.

[6] Ray S, Britschgi M, Herbert C, Takeda-Uchimura Y, Boxer A, Blennow K, Friedman LF, Galasko DR, Jutel M, Karydas A, Kaye JA, Leszek J, Miller BL, Minthon L, Quinn JF, Rabinovici GD, Robinson WH, Sabbagh MN, So YT, Sparks DL, Tabaton M, Tinklenberg J, Yesavage JA, Tibshirani R, Wyss-Coray T (2007) Classification and prediction of clinical Alzheimer's diagnosis based on plasma signaling proteins. Nature Medicine 13, 1359-1362.

[7] Sattlecker M, Kiddle SJ, Newhouse S, Proitsi P, Nelson S, Williams S, Johnston C, Killick R, Simmons A, Westman E, Hodges A, Soininen H, Kloszewska I, Mecocci P, Tsolaki M, Vellas B, Lovestone S, the AddNeuroMed C, Dobson RJ (2014) Alzheimer's disease biomarker discovery using SOMAscan multiplexed protein technology. Alzheimers Dement.

[8] Schneider P, Hampel H, Buerger K (2009) Biological Marker Candidates of Alzheimer's Disease in Blood, Plasma, and Serum. Cns Neuroscience \& Therapeutics 15, 358-374.

[9] Thambisetty M, Hye A, Foy C, Daly E, Glover A, Cooper A, Simmons A, Murphy D, Lovestone S (2008) Proteome-based identification of plasma proteins associated with hippocampal metabolism in early Alzheimer's disease. Journal of Neurology 255, 1712-1720.

[10] Thambisetty M, Simmons A, Velayudhan L, Hye A, Campbell J, Zhang Y, Wahlund LO, Westman E, Kinsey A, Guntert A, Proitsi P, Powell J, Causevic M, Killick R, Lunnon K, Lynham S, Broadstock M, Choudhry F, Howlett DR, Williams RJ, Sharp SI, Mitchelmore C, Tunnard C, Leung R, Foy C, O'Brien D, Breen G, Furney SJ, Ward M, Kloszewska I, Mecocci P, Soininen H, Tsolaki M, Vellas B, Hodges A, Murphy DGM, Parkins S, Richardson JC, Resnick SM, Ferrucci L, Wong DF, Zhou Y, Muehlboeck S, Evans A, Francis PT, Spenger C, Lovestone S (2010) Association of Plasma Clusterin Concentration With Severity, Pathology, and Progression in Alzheimer Disease. Archives of General Psychiatry 67, 739-748.

[11] Lovestone S, Francis P, Strandgaard K (2007) Biomarkers for disease modification trials--the innovative medicines initiative and AddNeuroMed. $J$ Nutr Health Aging 11, 359-361.

[12] Lovestone S, Francis P, Kloszewska I, Mecocci P, Simmons A, Soininen H, Spenger C, Tsolaki M, Vellas B, Wahlund LO, Ward M, AddNeuroMed C (2009) AddNeuroMed--the European collaboration for the discovery of novel biomarkers for Alzheimer's disease. Ann N Y Acad Sci 1180, 36-46.

[13] Gold L, Ayers D, Bertino J, Bock C, Bock A, Brody EN, Carter J, Dalby AB, Eaton BE, Fitzwater T, Flather D, Forbes A, Foreman T, Fowler C, Gawande B, Goss M, Gunn M, Gupta S, Halladay D, Heil J, Heilig J, Hicke B, Husar G, Janjic J, Jarvis T, Jennings S, Katilius E, Keeney TR, Kim N, Koch TH, Kraemer S, Kroiss L, Le N, Levine D, Lindsey W, Lollo B, Mayfield W, Mehan M, Mehler R, Nelson SK, Nelson M, Nieuwlandt D, Nikrad M, Ochsner U, Ostroff RM, Otis M, Parker T, Pietrasiewicz S, Resnicow DI, Rohloff J, Sanders G, Sattin S, Schneider D, Singer B, Stanton M, Sterkel A, Stewart A, Stratford S, Vaught JD, Vrkljan M, Walker JJ, Watrobka M, Waugh S, Weiss A, Wilcox SK, Wolfson A, Wolk SK, Zhang C, Zichi D (2010) Aptamer-Based Multiplexed Proteomic Technology for Biomarker Discovery. Plos One 5.

[14] Pinheiro J, Bates D, DebRoy S, Sarkar D, Team RC nlme: Linear and Nonlinear Mixed Effects Models, 2012. R package version, 3.1-105.

[15] Huang DW, Sherman BT, Lempicki RA (2009) Systematic and integrative analysis of large gene lists using DAVID bioinformatics resources. Nature Protocols 4, 44-57.

[16] Huang DW, Sherman BT, Lempicki RA (2009) Bioinformatics enrichment tools: paths toward the comprehensive functional analysis of large gene lists. Nucleic Acids Research 37, 1-13.

[17] Akiyama H, Barger S, Barnum S, Bradt B, Bauer J, Cole GM, Cooper NR, Eikelenboom $\mathrm{P}$, Emmerling $\mathrm{M}$, Fiebich $\mathrm{BL}$, Finch $\mathrm{CE}$, Frautschy $\mathrm{S}$, Griffin WS, Hampel H, Hull M, Landreth G, Lue L, Mrak R, Mackenzie IR, McGeer PL, O'Banion MK, Pachter J, Pasinetti G, Plata-Salaman C, Rogers J, Rydel R, Shen Y, Streit W, Strohmeyer R, Tooyoma I, Van Muiswinkel FL, Veerhuis R, Walker D, Webster S, 
Wegrzyniak B, Wenk G, Wyss-Coray T (2000) Inflammation and Alzheimer's disease. Neurobiol Aging 21, 383-421.

[18] Bradt BM, Kolb WP, Cooper NR (1998) Complement-dependent proinflammatory properties of the Alzheimer's disease beta-peptide. J Exp Med 188, 431-438.

[19] Walport MJ (2001) Advances in immunology: Complement (First of two parts). New England Journal of Medicine 344, 1058-1066.

[20] Bonifati DM, Kishore U (2007) Role of complement in neurodegeneration and neuroinflammation. Molecular Immunology 44, 999-1010.

[21] Thiel S (2007) Complement activating soluble pattern recognition molecules with collagen-like regions, mannan-binding lectin, ficolins and associated proteins. Mol Immunol 44, 3875-3888.

[22] Kishore U, Gupta SK, Perdikoulis MV, Kojouharova MS, Urban BC, Reid KBM (2003) Modular organization of the carboxyl-terminal, globular head region of human C1q A, $\mathrm{B}$, and $\mathrm{C}$ chains. Journal of Immunology 171, 812-820.

[23] Duong T, Pommier EC, Scheibel AB (1989) Immunodetection of the Amyloid-P Component in Alzheimers-Disease. Acta Neuropathologica 78, 429-437.

[24] Duong TH, Nikolaeva M, Acton PJ (1997) C-reactive protein-like immunoreactivity in the neurofibrillary tangles of Alzheimer's disease. Brain Research 749, 152-156.

[25] McGeer EG, Yasojima K, Schwab C, McGeer PL (2001) The pentraxins: possible role in Alzheimer's disease and other innate inflammatory diseases. Neurobiol Aging 22, 843-848.

[26] Urbanyi Z, Lakics V, Erdo SL (1994) Serum Amyloid-P Component-Induced CellDeath in Primary Cultures of Rat Cerebral-Cortex. European Journal of Pharmacology-Environmental Toxicology and Pharmacology Section 270, 375-378.

[27] Urbanyi Z, Laszlo L, Tomasi TB, Toth E, Mekes E, Sass M, Pazmany T (2003) Serum amyloid $\mathrm{P}$ component induces neuronal apoptosis and beta-amyloid immunoreactivity. Brain Research 988, 69-77.

[28] Pepys MB, Herbert J, Hutchinson WL, Tennent GA, Lachmann HJ, Gallimore JR, Lovat LB, Bartfai T, Alanine A, Hertel C, Hoffmann T, Jakob-Roetne R, Norcross RD, Kemp JA, Yamamura K, Suzuki M, Taylor GW, Murray S, Thompson D, Purvis A, Kolstoe S, Wood SP, Hawkins PN (2002) Targeted pharmacological depletion of serum amyloid $\mathrm{P}$ component for treatment of human amyloidosis. Nature 417, 254259.

[29] Ying SC, Gewurz AT, Jiang HX, Gewurz H (1993) Human Serum Amyloid-P Component Oligomers Bind and Activate the Classical Complement Pathway Via Residue-14-26 and Residue-76-92 of the a-Chain Collagen-Like Region of C1q. Journal of Immunology 150, 169-176.

[30] Hu WT, Holtzman DM, Fagan AM, Shaw LM, Perrin R, Arnold SE, Grossman M, Xiong C, Craig-Schapiro R, Clark CM, Pickering E, Kuhn M, Chen Y, Van Deerlin VM, McCluskey L, Elman L, Karlawish J, Chen-Plotkin A, Hurtig HI, Siderowf A, Swenson F, Lee VM, Morris JC, Trojanowski JQ, Soares H, Alzheimer's Disease Neuroimaging I (2012) Plasma multianalyte profiling in mild cognitive impairment and Alzheimer disease. Neurology 79, 897-905.

[31] Kiddle SJ, Thambisetty M, Simmons A, Riddoch-Contreras J, Hye A, Westman E, Pike I, Ward M, Johnston C, Lupton MK, Lunnon K, Soininen H, Kloszewska I, Tsolaki M, Vellas B, Mecocci P, Lovestone S, Newhouse S, Dobson R, Alzheimers Disease Neuroimaging I (2012) Plasma based markers of [11C] PiB-PET brain amyloid burden. PLoS One 7, e44260.

[32] Doecke JD, Laws SM, Faux NG, Wilson W, Burnham SC, Lam CP, Mondal A, Bedo J, Bush AI, Brown B, De Ruyck K, Ellis KA, Fowler C, Gupta VB, Head R, Macaulay SL, Pertile K, Rowe CC, Rembach A, Rodrigues M, Rumble R, Szoeke C, Taddei K, Taddei T, Trounson B, Ames D, Masters CL, Martins RN, for the Alzheimer's Disease Neuroimaging I, Australian Imaging B, Lifestyle Research G (2012) Blood-Based Protein Biomarkers for Diagnosis of Alzheimer Disease. Arch Neurol, 1-8.

[33] Soares HD, Potter WZ, Pickering E, Kuhn M, Immermann FW, Shera DM, Ferm M, Dean RA, Simon AJ, Swenson F, Siuciak JA, Kaplow J, Thambisetty M, Zagouras P, Koroshetz WJ, Wan HI, Trojanowski JQ, Shaw LM, for the Biomarkers Consortium Alzheimer's Disease Plasma Proteomics P (2012) Plasma Biomarkers Associated With the Apolipoprotein E Genotype and Alzheimer Disease. Arch Neurol, 1-8. 
[34] Furney SJ, Kronenberg D, Simmons A, Guntert A, Dobson RJ, Proitsi P, Wahlund LO, Kloszewska I, Mecocci P, Soininen H, Tsolaki M, Vellas B, Spenger C, Lovestone S (2011) Combinatorial markers of mild cognitive impairment conversion to Alzheimer's disease--cytokines and MRI measures together predict disease progression. J Alzheimers Dis 26 Suppl 3, 395-405.

[35] Leung R, Proitsi P, Simmons A, Lunnon K, Guntert A, Kronenberg D, Pritchard M, Tsolaki M, Mecocci P, Kloszewska I, Vellas B, Soininen H, Wahlund LO, Lovestone S (2013) Inflammatory Proteins in Plasma Are Associated with Severity of Alzheimer's Disease. Plos One 8.

[36] Banisadr G, Rostene W, Kitabgi P, Parsadaniantz SM (2005) Chemokines and brain functions. Curr Drug Targets Inflamm Allergy 4, 387-399.

[37] Banisadr G, Skrzydelski D, Kitabgi P, Rostene W, Parsadaniantz SM (2003) Highly regionalized distribution of stromal cell-derived factor-1/CXCL12 in adult rat brain: constitutive expression in cholinergic, dopaminergic and vasopressinergic neurons. European Journal of Neuroscience 18, 1593-1606.

[38] Guyon A, Nahon JL (2007) Multiple actions of the chemokine stromal cell-derived factor-1 alpha on neuronal activity. Journal of Molecular Endocrinology 38, 365-376.

[39] Ijsselstijn L, Dekker LJ, Stingl C, van der Weiden MM, Hofman A, Kros JM, Koudstaal PJ, Sillevis Smitt PA, Ikram MA, Breteler MM, Luider TM (2011) Serum levels of pregnancy zone protein are elevated in presymptomatic Alzheimer's disease. $J$ Proteome Res 10, 4902-4910.

[40] Chiam JT, Dobson RJ, Kiddle SJ, Sattlecker M (2014) Are Blood-Based Protein Biomarkers for Alzheimer's Disease also Involved in Other Brain Disorders? A Systematic Review. J Alzheimers Dis.

[41] Alberio T, Bucci EM, Natale M, Bonino D, Di Giovanni M, Bottacchi E, Fasano M (2013) Parkinson's disease plasma biomarkers: an automated literature analysis followed by experimental validation. J Proteomics 90, 107-114.

[42] Goldknopf IL, Bryson JK, Strelets I, Quintero S, Sheta EA, Mosqueda M, Park HR, Appel SH, Shill H, Sabbagh M, Chase B, Kaldjian E, Markopoulou K (2009) Abnormal serum concentrations of proteins in Parkinson's disease. Biochem Biophys Res Commun 389, 321-327.

[43] Jimenez-Jimenez FJ, Fernandez-Calle P, Martinez-Vanaclocha M, Herrero E, Molina JA, Vazquez A, Codoceo R (1992) Serum levels of zinc and copper in patients with Parkinson's disease. J Neurol Sci 112, 30-33.

[44] Usha A, D'Souza J, Kousalya R, Rao G, Nandini M, V Ds (2006) Total antioxidant activity in parkinson's disease. Biomed Res 17, 145-147.

[45] Huang TL (2002) Decreased serum albumin levels in Taiwanese patients with schizophrenia. Psychiatry Clin Neurosci 56, 627-630.

[46] Pae CU, Paik IH, Lee C, Lee SJ, Kim JJ, Lee CU (2004) Decreased plasma antioxidants in schizophrenia. Neuropsychobiology 50, 54-56.

[47] Reddy R, Keshavan M, Yao JK (2003) Reduced plasma antioxidants in first-episode patients with schizophrenia. Schizophr Res 62, 205-212.

[48] Hung KC, Wu CC, Chen HS, Ma WY, Tseng CF, Yang LK, Hsieh HL, Lu KC (2011) Serum IL-6, albumin and comorbidities are closely correlated with symptoms of depression in patients on maintenance haemodialysis. Nephrology Dialysis Transplantation 26, 658-664.

[49] Kalender B, Ozdemir AC, Koroglu G (2006) Association of depression with markers of nutrition and inflammation in chronic kidney disease and end-stage renal disease. Nephron Clin Pract 102, c115-121.

[50] Maes M, Wauters A, Neels H, Scharpé S, Van Gastel A, D'Hondt P, Peeters D, Cosyns P, Desnyder R (1995) Total serum protein and serum protein fractions in depression: relationships to depressive symptoms and glucocorticoid activity. Journal of affective disorders 34, 61-69.

[51] Nunes SOV, Reiche EMV, Morimoto HK, Matsuo T, Itano EN, Xavier ECD, Yamashita CM, Vieira VR, Menoli AV, Silva SS, Costa FB, Reiche FV, Silva FLV, Kaminami MS (2002) Immune and hormonal activity in adults suffering from depression. Brazilian Journal of Medical and Biological Research 35, 581-587.

[52] Park HC, Lee H, Lee JP, Kim DK, Oh KH, Joo KW, Lim CS, Kim YS, Ahn C, Oh YK (2012) Lower Residual Renal Function is a Risk Factor for Depression and Impaired 
Health-Related Quality of Life in Korean Peritoneal Dialysis Patients. Journal of Korean Medical Science 27, 64-71.

[53] Song C, Dinan T, Leonard BE (1994) Changes in immunoglobulin, complement and acute phase protein levels in the depressed patients and normal controls. $J$ Affect Disord 30, 283-288.

[54] Soto C, Castano EM (1996) The conformation of Alzheimer's beta peptide determines the rate of amyloid formation and its resistance to proteolysis. Biochem J $\mathbf{3 1 4}$ ( Pt 2), 701-707.

[55] Chauhan V, Sheikh AM, Chauhan A, Spivack WD, Fenko MD, Malik MN (2005) Fibrillar amyloid beta-protein inhibits the activity of high molecular weight brain protease and trypsin. J Alzheimers Dis 7, 37-44. 
Table 1 Sample characteristics stratified by clinical diagnostic group. P-values comparing the different diagnostic groups were calculated using a one-way ANOVA. (MCl - Mild Cognitive Impaired, AD - Alzheimer's disease)

\begin{tabular}{lccccc}
\hline & Control & MCl stable & MCl converting & AD & P-Value \\
& 69 & 37 & 39 & 90 & 0.003 \\
Age (median [IQR]) & $74.0[9.00]$ & $75.0[8.00]$ & $77.0[10.00]$ & $76.0[9.75]$ & 0.234 \\
Gender (male/female) & $33 / 36$ & $15 / 22$ & $17 / 22$ & $29 / 61$ & $<0.001$ \\
Number of APOE e4 & $48 / 18 / 3$ & $24 / 12 / 1$ & $15 / 21 / 3$ & $39 / 36 / 15$ & $<0.001$ \\
alleles (0/1/2) & & & & $22[7]$ & \\
Baseline MMSE & $29[2]$ & $28[2]$ & $27[3]$ & & \\
(median [IQR]) & & & &
\end{tabular}


Table 2: Proteins whose level changes over time are associated with the rate of cognitive decline. A negative Beta value indicates higher levels in AD patients with fast cognitive decline; a positive Beta value indicates a lower levels in rapidly declining patients.

\begin{tabular}{lllrrr}
\hline Protein & Short name & UniProt & Beta & p-Value & q-Value \\
\hline Complement C2 & C2 & P06681 & -0.031 & $1.9 E-5$ & 0.019 \\
Serum amyloid A-1 protein & SAA & P02735 & -0.003 & $5.4 E-5$ & 0.027 \\
Complement C9 & C9 & P02748 & -0.014 & $1.8 E-4$ & 0.055 \\
Mannose-binding protein C & MBL & P11226 & -0.010 & $2.2 E-4$ & 0.055 \\
Serum amyloid P-component & SAP & P02743 & -0.014 & $3.9 E-4$ & 0.079 \\
a2-Antiplasmin & & P08697 & -0.021 & 0.003 & 0.377 \\
Serine/threonine-protein kinase Chk1 & Chk1 & O14757 & -0.027 & 0.003 & 0.377 \\
Interleukin-17A & IL17 & Q16552 & -0.021 & 0.004 & 0.500 \\
Eukaryotic translation initiation factor & elF-5A-1 & P63241 & 0.011 & 0.006 & 0.645 \\
5A-1 & & P02790 & -0.009 & 0.007 & 0.645 \\
Hemopexin & & Q16543 & 0.021 & 0.008 & 0.645 \\
C-C motif chemokine 19 & CDC37 & Q9BXR6 & -0.010 & 0.008 & 0.645 \\
Complement factor H-related protein 5 & & & &
\end{tabular}


Table 3. Proteins shown to be changing over time at least one of the disease groups (qvalue $<0.05$ ). Beta $(B)$ coefficients represent diagnosis $x$ time interactions and thus a negative Beta means that the protein levels decrease as disease progresses.. [DC-SIGNR (C-type lectin domain family 4 member M), MIP-1a (C-C motif chemokine 3), RGM-A (Repulsive guidance molecule A), BMP-RII (Bone morphogenetic protein receptor type-2), CD39 (Ectonucleoside triphosphate diphosphohydrolase 1), Ck- $\beta-8-1$ (C-C motif chemokine 23), VEGF (Vascular endothelial growth factor A), EphA1 (Ephrin type-A receptor 1) and HCC-1 (C-C motif chemokine 14)]

\begin{tabular}{|c|c|c|c|c|c|c|c|c|c|c|}
\hline \multirow[b]{2}{*}{ Protein } & \multirow[b]{2}{*}{ UniProt } & \multicolumn{3}{|c|}{$\mathrm{MCl}$ stable } & \multicolumn{3}{|c|}{$\mathrm{MCl}$ converter } & \multicolumn{3}{|c|}{ Alzheimer's Disease } \\
\hline & & Beta & p-Value & q-Value & Beta & p-Value & q-Val & Beta & $p$-Value & q-Value \\
\hline DC-SIGNR & Q9H2X3 & $-1.6 \mathrm{E}-4$ & 0.224 & 0.994 & $-2.9 \mathrm{E}-4$ & 0.026 & 0.999 & $-5.9 \mathrm{E}-4$ & $3.2 E-8$ & 3.E-5 \\
\hline & 014965 & $1.6 \mathrm{E}-5$ & 0.831 & 0.994 & $-1.4 \mathrm{E}-4$ & 0.069 & 0.999 & $-2.8 \mathrm{E}-4$ & $3.8 \mathrm{E}-6$ & 0.002 \\
\hline MIP-1 $1 \alpha$ & P10147 & $-2.0 \mathrm{E}-5$ & 0.834 & 0.994 & $-4.0 \mathrm{E}-5$ & 0.668 & 0.999 & $-3.4 \mathrm{E}-4$ & $9.9 \mathrm{E}-6$ & 0.003 \\
\hline RGM-A & Q96B86 & $-2.2 \mathrm{E}-5$ & 0.809 & 0.994 & $-1.7 \mathrm{E}-4$ & 0.060 & 0.999 & $-3.2 \mathrm{E}-4$ & $1.3 \mathrm{E}-5$ & 0.003 \\
\hline BMP-RII & Q13873 & $9.7 \mathrm{E}-5$ & 0.292 & 0.994 & $-1.6 \mathrm{E}-4$ & 0.086 & 0.999 & $-3.1 \mathrm{E}-4$ & $2.4 \mathrm{E}-5$ & 0.004 \\
\hline CD39 & P49961 & $2.5 \mathrm{E}-5$ & 0.731 & 0.994 & $-8.3 E-5$ & 0.244 & 0.999 & $-2.4 \mathrm{E}-4$ & $2.5 E-5$ & 0.004 \\
\hline Kallikrein 14 & Q9P0G3 & $3.9 \mathrm{E}-5$ & 0.605 & 0.994 & $-1.8 \mathrm{E}-4$ & 0.017 & 0.999 & $-2.5 \mathrm{E}-4$ & $5.3 E-5$ & 0.008 \\
\hline Ck- $\beta-8-1$ & P55773 & $-7.7 \mathrm{E}-5$ & 0.434 & 0.994 & $-9.3 E-5$ & 0.339 & 0.999 & $-3.1 \mathrm{E}-4$ & $9.6 \mathrm{E}-5$ & 0.011 \\
\hline VEGF & P15692 & $-8.0 \mathrm{E}-5$ & 0.220 & 0.994 & $-8.9 \mathrm{E}-5$ & 0.171 & 0.999 & $-2.1 \mathrm{E}-4$ & $9.2 \mathrm{E}-5$ & 0.011 \\
\hline EphA1 & P21709 & $4.9 \mathrm{E}-6$ & 0.972 & 0.994 & $-6.7 \mathrm{E}-5$ & 0.628 & 0.999 & $-4.3 E-4$ & $1.1 \mathrm{E}-4$ & 0.011 \\
\hline HCC-1 & Q16627 & $-8.2 \mathrm{E}-4$ & $5.9 \mathrm{E}-6$ & 0.006 & $-9.3 E-5$ & 0.598 & 0.999 & $-4.9 \mathrm{E}-4$ & $6.1 \mathrm{E}-4$ & 0.051 \\
\hline
\end{tabular}


Table 4. Proteins that were found to change ( $\mathrm{p}$-value $<0.01$ ) during the conversion from $\mathrm{MCl}$ to $A D$ relative to the stable $\mathrm{MCl}$ group

\begin{tabular}{lllrrr}
\hline Protein name & Short name & UniProt & Beta & p-value & q-value \\
\hline Stromal cell-derived factor 1 & SDF-1a & P48061 & $3.3 E-4$ & $9.6 E-5$ & 0.098 \\
Antileukoproteinase & SLPI & P03973 & $4.8 E-4$ & $8.5 E-4$ & 0.434 \\
C-C motif chemokine 14 & HCC-1 & Q16627 & $7.3 E-4$ & 0.002 & 0.695 \\
$\begin{array}{l}\text { Tumor necrosis factor receptor } \\
\text { superfamily member 17 }\end{array}$ & BCMA & Q02223 & $3.8 E-4$ & 0.005 & 0.911 \\
Leukotriene A-4 hydrolase & LTA-4 hydrolase & P09960 & $2.1 \mathrm{E}-4$ & 0.006 & 0.911 \\
Endostatin & & P39060 & $4.0 E-4$ & 0.006 & 0.911 \\
Trypsin & & P07477 & $4.9 E-4$ & 0.006 & 0.911 \\
Interleukin-6 receptor subunit alpha & IL-6 sRa & P08887 & $3.4 E-4$ & 0.007 & 0.911 \\
Albumin & & P02768 & $2.6 E-4$ & 0.010 & 0.999
\end{tabular}


Figure 1. Scatter plots showing the four most significant protein level changes associated with the rate of decline. All proteins four protein show a greater increase in faster declining patients than in slow declining patients. Complement C2, Complement C9 and Mannose-binding proteins are members of the complement cascade.
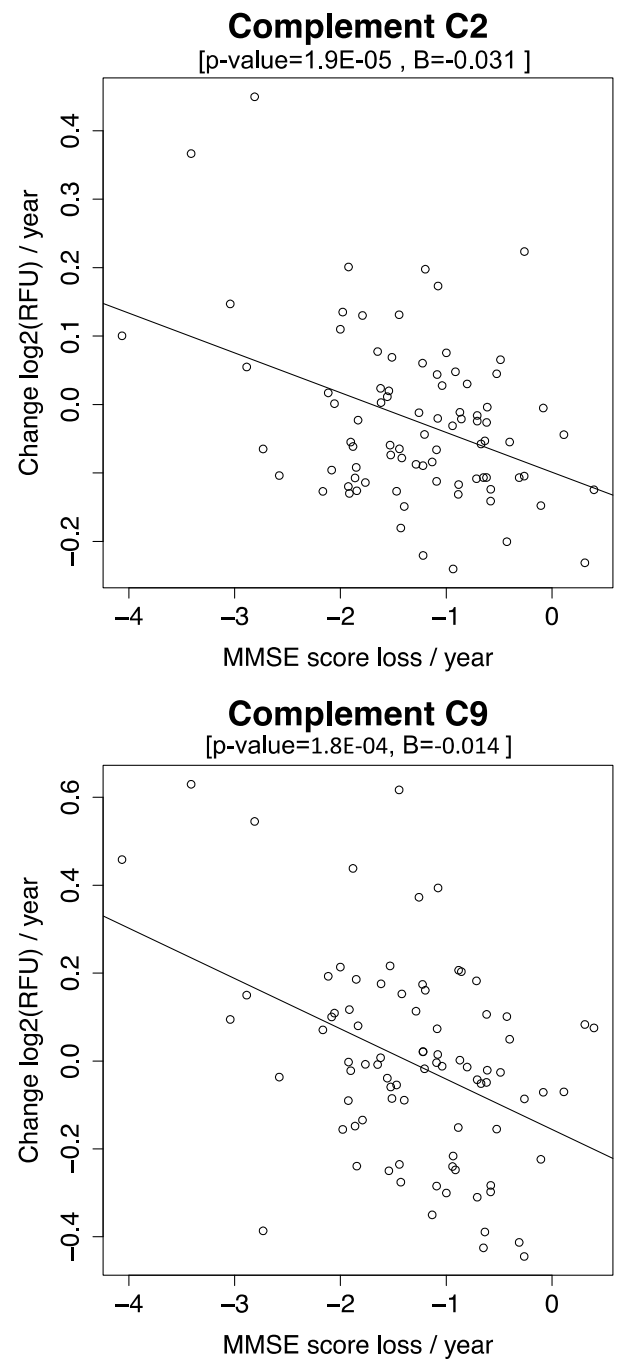
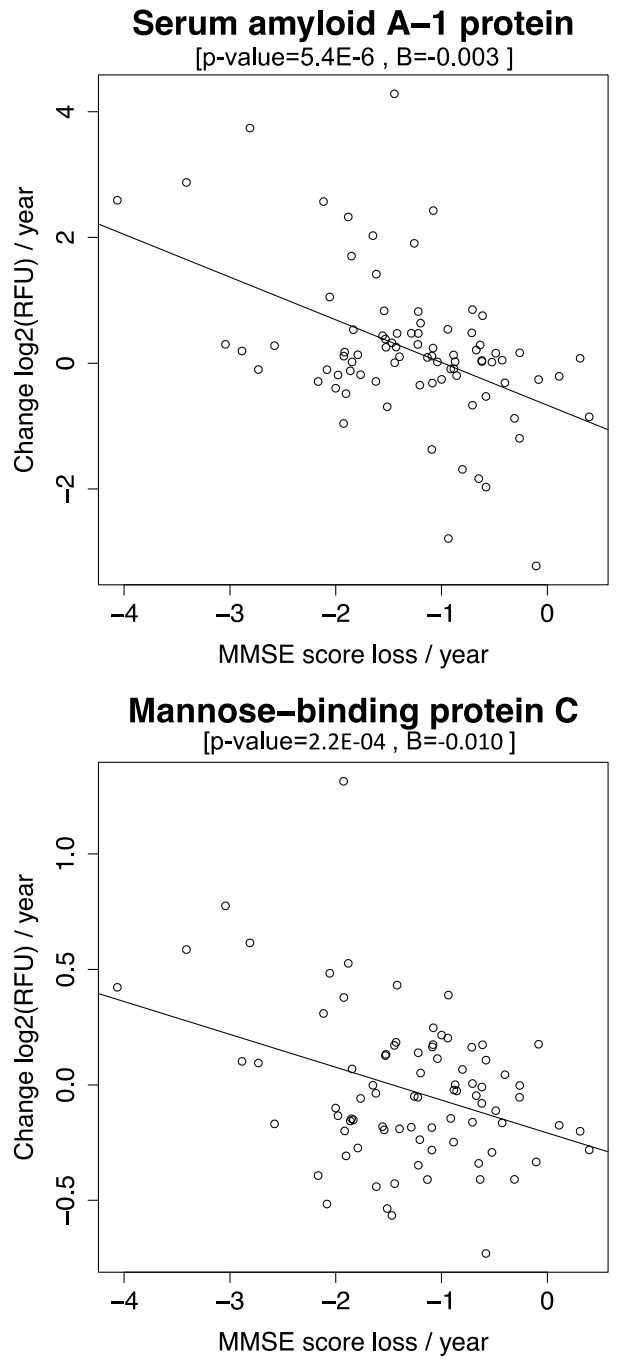
Figure 2. Changes in plasma levels for the four most significantly changing proteins for each of the diagnostic groups compared to normal aging controls (CTL). All four proteins appear to slowly increase in abundance in healthy aging, which is reduced and even reversed in AD.
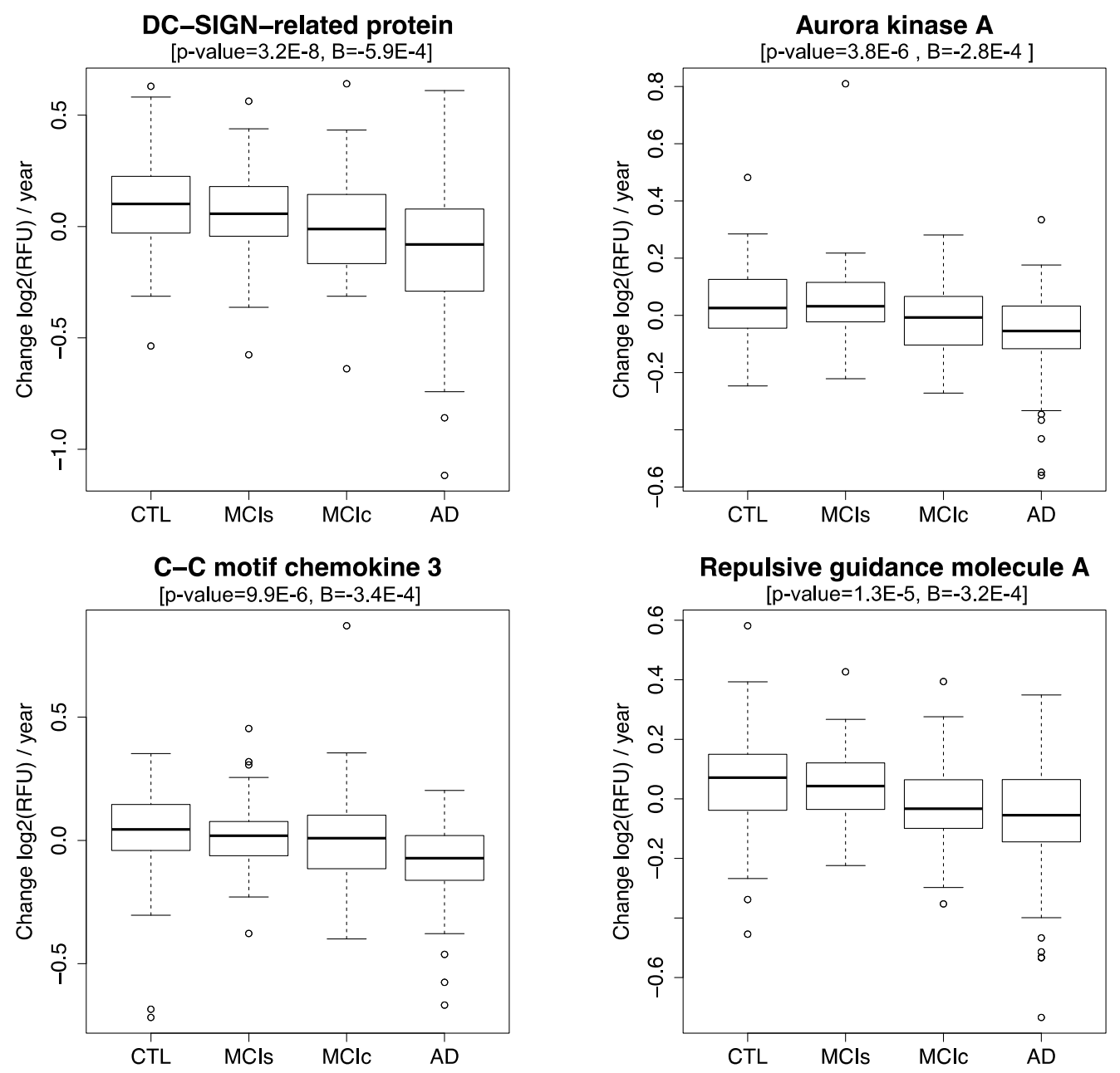

Repulsive guidance molecule A

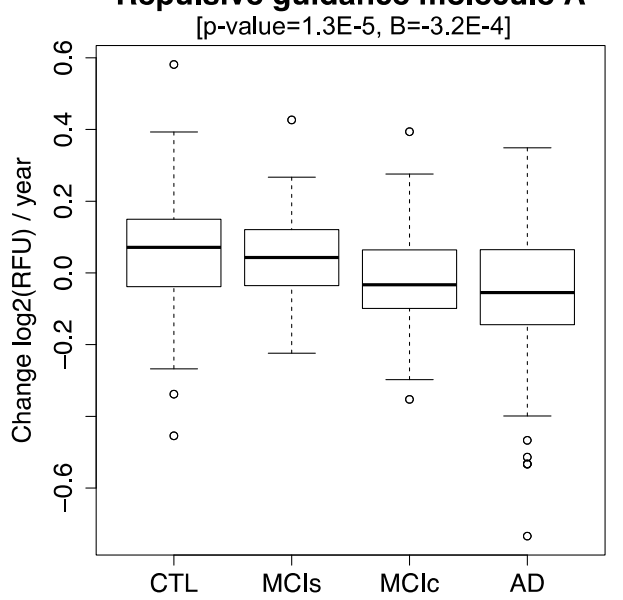


